\title{
Work-related fatigue: the specific case of highly educated women in the Netherlands
}

\author{
Petra Verdonk • Wendela E. Hooftman • \\ Marc J. P. M. van Veldhoven • Louise R. M. Boelens • \\ Lando L. J. Koppes
}

Received: 2 April 2009 / Accepted: 16 October 2009 / Published online: 4 November 2009

(C) The Author(s) 2009. This article is published with open access at Springerlink.com

\begin{abstract}
Purpose This study aims to establish the prevalence of high work-related fatigue (need for recovery, NFR) among employees and to explain group differences categorized by gender, age, and education. The study particularly aims to clarify prevalence and explanatory factors in highly educated women.

Methods In 2005 and 2006, large representative samples of 80,000 Dutch employees (net response rate 33.0\%; $N=47,263)$ received the Netherlands working conditions survey questionnaire. First, we calculated the prevalence of high NFR for men and women with different age and education levels. The average prevalence of high NFR was $28.8 \%$ and was highest among highly educated women
\end{abstract}

\author{
P. Verdonk $(\square)$ \\ Caphri, Social Medicine, Maastricht University, \\ Universiteitssingel 40, P.O. Box 616, \\ 6200 MD Maastricht, The Netherlands \\ e-mail: petra.verdonk@socmed.unimaas.nl \\ W. E. Hooftman · L. L. J. Koppes \\ TNO Quality of Life, Division Work and Employment, \\ Polarisavenue 151, P.O. Box 718, \\ 2130 AS Hoofddorp, The Netherlands \\ e-mail: wendela.hooftman@tno.nl \\ L. L. J. Koppes \\ e-mail: lando.koppes@tno.nl
}

M. J. P. M. van Veldhoven

Human Resource Studies, Tilburg University, Warandelaan 2,

P.O. Box 90153, 5000 LE Tilburg, The Netherlands

e-mail: m.j.p.m.vanveldhoven@uvt.nl

\section{R. M. Boelens}

Bureau Boelens, Willem Barentszstraat 56,

3572 PL Utrecht, The Netherlands

e-mail: info@louiseboelens.nl
$(35.2 \%)$ in particular those aged $50-64$ years $(40.3 \%)$. Second, logistic regression analyses were used to compare subgroups' NFR in relation to situational factors, working conditions, and health. Three comparisons were made: (1) highly educated women versus men; (2) highly educated versus lower educated women and; (3) older highly educated versus younger highly educated women.

Results The situational, working conditions and health factors in our model did not explain the gender differences among highly educated employees $(\mathrm{OR}=1.37$; $\mathrm{CI}=1.3$ 1.5, adjusted for all factors $\mathrm{OR}=1.32$; $\mathrm{CI}=1.2-1.5$ ). Despite that lower autonomy and workplace violence explained highly educated women's NFR, working fewer hours counterbalanced this. Time pressure in work largely explained the differences in NFR among women at different education levels (crude OR 1.44; $\mathrm{CI}=1.4-1.5$, adjusted OR 1.14; $\mathrm{CI}=1.0-1.3)$. In the age comparison, lower health ratings, more adverse working conditions, and working as a teacher explained older highly educated women's high prevalence of high NFR (crude OR 1.32; CI $=1.2-1.5$, adjusted OR 0.94; $\mathrm{CI}=0.8-1.2$ ).

Conclusion NFR has high prevalence in highly educated women $(35.2 \%)$ in particular those aged 50-64 years $(40.3 \%)$. Our model did not explain gender differences in NFR, because working fewer hours counterbalanced the effects of lower autonomy and external workplace violence. Our model, in particular time pressure, largely explained differences in NFR between women at different education levels. Age differences in the prevalence of high NFR among highly educated women's were fully explained by our model. Main factors were lower health ratings, adverse working conditions, and working as a teacher.

Keywords Need for recovery - Work-related fatigue . Gender · Highly educated women · Working conditions 


\section{Introduction}

Women report more fatigue than men (Nelson and Burke 2002; Pugliesi 1999; Macintyre et al. 1996), whether this concerns mental fatigue, physical fatigue, sleepiness, feeling tired, or emotional exhaustion (Bakker et al. 2002; Åkerstedt et al. 2004). Women also report sleeping disorders more often than men (Åkerstedt et al. 2004; PerettiWatel et al. 2009). More women indicate fatigue symptoms to their general practitioner, and they consume more drugs for insomnia (Peretti-Watel et al. 2009; Meeuwesen et al. 2002). Study findings suggest that women are more at risk of work-related fatigue than men, but the evidence regarding education and age is less clear. Our study aims to provide insight which group(s) distinguished by demographic factors report(s) high fatigue, and to what extent group differences can be explained by situational and workrelated factors. The study is conducted among a large representative sample of Dutch employees.

Need for recovery (NFR) after work is an indicator for work-related fatigue and reflects the workers' "sense of urgency to take a break" or the necessity for unwinding after work (Sonnentag and Zijlstra 2006). NFR is to be interpreted within the context of the Effort-Recovery Model which describes how job demands produce costs in terms of emotional, cognitive, and behavioral symptoms as consequences of short-term fatigue (Meijman and Mulder 1998; Van Veldhoven 2008). The Effort-Recovery Model is an extension of the job demand-control JD-C model which explains job stress as well as learning from the balance between experienced job demands and job control (Karasek and Theorell 1990). Working conditions such as job control and working overtime may influence the translation of job demands into fatigue. Short-term fatigue at work is reversible for instance by work breaks, holidays, or leisure time. When insufficient possibilities exist for recovery during or after work or over a longer period of time, a cumulative effect occurs in which NFR increases (Meijman and Zijlstra 2007; Jansen et al. 2003). Such increased NFR may require extra mental effort during the following working day. Eventually, this may result in more severe health problems. A high NFR may express itself in stress symptoms such as feelings of overload, irritability, social withdrawal, or the lack of energy for new effort (Van Veldhoven and Broersen 2003). Evidence for the concept's predictive value was found in several studies. For instance, high NFR predicts sickness absence duration (De Croon et al. 2003) and turnover in truck drivers (De Croon et al. 2004), coronary heart disease (Van Amelsvoort et al. 2003), accidents at work (Swaen et al. 2003), and subjective health complaints such as emotional exhaustion and sleeping problems (Sluiter et al. 2003). Conceptually, NFR bridges the phase between regular effort in work and severe, long-term fatigue. The latter is central to stress-related psychological health problems such as vital exhaustion, adjustment disorders, and burnout (Van Veldhoven and Broersen 2003). A prolonged period of high NFR indicates failing recovery. This eventually may compromise health, work performance, and quality of life (Van Veldhoven 2008).

In the Netherlands, more women than men report fatigue, in particular highly educated women (Meeuwesen et al. 2002; Bensing et al. 1999). A recent study in Flanders showed gender and age differences in NFR among public sector workers. Employees older than 45 years and female employees reported a higher NFR than younger employees and than male employees (Kiss et al. 2008). And although gender differences in overall NFR scores were not found, in the Netherlands in particular highly educated women aged 45 years and older reported high NFR (Van Veldhoven and Broersen 1999). This finding was replicated for highly educated women older than 50 years (Boelens 2007). As regards other work-related fatigue measures, in the Maastricht Cohort Study in particular lower educated employees and younger employees reported more burnout than intermediate and highly educated employees and than older employees (Kant et al. 2003). One study found higher emotional exhaustion rates in young women (Bakker et al. 2002), whereas other researchers found that the risk of emotional exhaustion increased with age for both genders (Åkerstedt et al. 2004) for instance among nurses (Bekker et al. 2005). Another study did not find gender nor age differences in emotional exhaustion among Dutch general practitioners (Twellaar et al. 2008). In other studies, subgroups of working women reported high levels of emotional exhaustion, particularly childless women either with or without a partner working fulltime or in a large part-time job (Otten et al. 2002; Lautenbach 2006).

The JD-C model predicts that high job demands such as working under time pressure combined with low control is particularly stressful (Karasek and Theorell 1990; Karasek et al. 1998). In the Netherlands, this unfavorable combination (high-strain jobs) occurs more often in women, whereas the most favorable combination of lower job demands and high control occurs more often in men (active jobs) (Otten et al. 2002). On the other hand, men more often work fulltime and overtime. In the health care sector, which is the largest employer of Dutch women, physical and psychosocial risk factors for occupational health problems such as emotional demands and workplace violence are high (Smulders and Klein Hesselink 1999). However, Dutch women have highly distinct career patterns from each other. Part-time work is more common among lower educated women, women with children, and among women working in the health care sector (Portegijs et al. 2008). Working conditions are likely to differ between women at different education levels, such as number of hours worked 
or physical job demands. The JD-C model predicts more stress in lower educated older women, because they work more often in high-strain jobs with high demands and low control (Doyal and Payne 2006; Verdonk and De Rijk 2008), whereas Dutch empirical evidence points toward more stress-related fatigue in young women working long hours (Lautenbach 2006). Hence, findings that a high NFR occurs in particular among older, highly educated working women cannot be straightforwardly explained and deserve more research (Van Veldhoven and Broersen 1999; Boelens 2007).

In this study, we use a national representative sample in order to gain more insight in the prevalence of fatigue in different subgroups distinguished by age, gender, and education level, as well as insight in explanations for high levels of fatigue. This leads us to the following research questions:

1. Which subgroup, distinguished by gender, age, and education level reports high work-related fatigue? How about the prevalence in highly educated women?

2. Which factors explain work-related fatigue in the subgroup with the highest prevalence compared with other subgroups? Which factors account for the prevalence in (older) highly educated women?

\section{Methods}

Sample and procedure

The Netherlands Working Conditions Survey (NWCS) is a combined postal/web survey which constitutes a representative sample of the Dutch workforce aged 15-64 years but excludes self-employed individuals (Van den Bossche et al. 2006, 2007). In 2005 and 2006, 80,000 individuals were randomly sampled from the Dutch working population database of Statistics Netherlands. Employees aged younger than 23 years and employees with a non-Western background were $50 \%$ over sampled, because the response rate in these two groups is known to be low. As the most recent database available for sampling was 2 years out of date, $10 \%$ of the individuals sampled did no longer meet the inclusion criteria of being an employee. Taking these $10 \%$ into account, the NWCS response rate was $33.0 \%(N=47,263)$.

The individuals in the sample received a written questionnaire by mail at their home address in the first week of November. The questionnaires were accompanied by an answering envelope and an information leaflet in which the purpose of the study was explained, and participation was asked. After 2-3 weeks, a written reminder was sent to the majority of those who had not yet responded. The questionnaire could be filled out with a pencil, or via internet using a personal code that was printed on the questionnaire. The individuals in the sample were given 7 weeks to fill out and return the questionnaire.

Measures

\section{Biographical data}

Biographical characteristics of the respondents are gender, four age categories $(15-29,30-39,40-49,50-64)$ and three categories for education level (low, intermediate level, and high).

\section{Situational factors}

Household composition is distinguished in five groups: married or co-habiting either with or without children, single parent household, single, or other. Nine professional groups were formed in accordance with the International Standard Classification of Occupations (ISCO).

\section{Working conditions and health}

In addition, information on working conditions was gathered. With regard to working time, the respondents were asked to report the number of hours they work according to their contract. Working overtime was asked in three categories (never, incidentally, on a structural basis).

Terms of employment were grouped to either fixed term or permanent. Organizational size was divided into three groups, small (1-9 employees), medium size (10-99 employees), and large organizations $\geq 100$ employees).

Job autonomy, time pressure, and emotional demands scales were constructed on the basis of, respectively, 5, 11, and 7 questions with answering options that ranged from '1-never' to '4-always'. Job autonomy is derived from the Job Content Questionnaire JCQ (Karasek et al. 1998; Van den Bossche et al. 2006, 2007). The time pressure and emotional demands scales are derived from the questionnaire on the experience and evaluation of work (VBBA) (Van Veldhoven et al. 2002). Several studies showed that construct validity, predictive validity, and internal consistency of the scales are fair to good (Karasek et al. 1998; Van Veldhoven et al. 2002). The scale scores were calculated by averaging the answers to the separate questions. Cronbach's alpha for these scales are 0.85, 0.87, and 0.80, respectively.

Separate dichotomous items were used to measure workplace violence and harassment by patients, students or passengers (external; three items; $\alpha=0.70$ ), and for workplace violence, and harassment by colleagues or superiors (internal; three items; $\alpha=0.59$ ). For internal and external workplace violence, questions were asked about unwanted 
sexual attention, intimidation, and physical violence in the past 12 months. If the answer to at least one of these three questions was 'yes', a positive scale score was given.

Satisfaction with working conditions and self-rated health were assessed with single item questions with five answering categories $(1=$ very dissatisfied to $5=$ very satisfied $)$.

\section{Work-related fatigue}

We measured work-related fatigue with the need for recovery after work scale (NFR) with 11 yes/no items $(\alpha=0.87)$ (Van Veldhoven and Broersen 2003). An example item is as follows: "I find it difficult to relax at the end of a working day." In this study, we dichotomized NFR scores as high and low. Employees with six or more positive responses are considered to have high NFR which identifies the high-risk group for NFR in the best possible way (Van Veldhoven 2008; Broersen et al. 2004). At this cutoff point, sensitivity and specificity of the scale are 79 and $72 \%$, and people with NFR $\geq 6$ have a higher risk of receiving treatment for psychological health complaints than people with a score $<6$. Test-retest reliability of NFR over a 2-year interval is good when applied in stable work environments and poor to fair when applied in unstable work environments, in truck drivers as well as in nurses (De Croon et al. 2006). Unstable work environments refer to changes for instance in supervisor or management, reorganizations, position, or working hours. The predictive value of NFR is confirmed for coronary heart disease (Van Amelsvoort et al. 2003), accidents at work (Swaen et al. 2003), as well as emotional exhaustion and sleeping problems (Sluiter et al. 2003).

\section{Analyses}

Despite good correspondence between the total population of Dutch employees and the 47,263 employees in the sample as regards gender, age, professional group, ethnic origin, geographic region, and educational level distributions, the responses were weighed for these factors. This weighing resulted in maximal correspondence between the employees who responded and the entire Dutch workforce (excluding self-employed). First, the prevalence of high NFR was calculated separately for men and women in the three educational groups and the four age groups. We present these findings in Fig. 1. The graph shows that high NFR is most prevalent among women with a high education level, and that among highly educated women, high NFR is most prevalent among those aged 50-64 years. Overall, the prevalence of high NFR was $28.8 \%$.

Based on this finding presented in Fig. 1, we chose to compare the prevalence of high NFR between groups using crude logistic regression analyses. We started with the

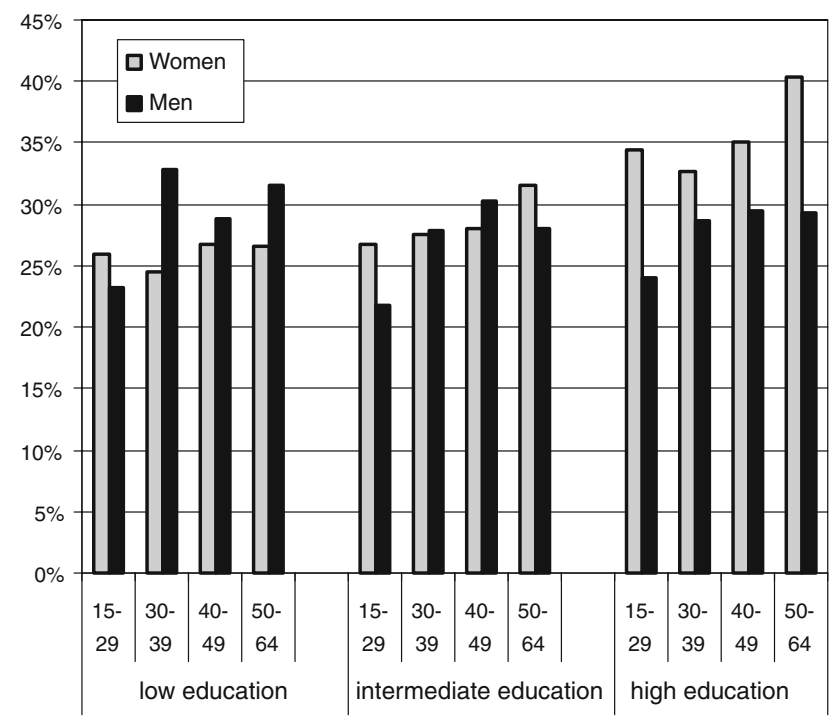

Fig. 1 Prevalence of high need for recovery for gender, education and age-specific group

comparison of highly educated women with highly educated men (gender comparison). Furthermore, we compared women with a high educational level with women with a low and intermediate educational level (education comparison) and women with a high education level aged 50-64 years with those aged 15-49 years (age comparison). We investigated the degree to which the crude differences in the prevalence of high NFR were influenced by adjustment for each of the other demographic, health, and workrelated factors studied. We present two types of results: one in which the factors are adjusted separately, and one with adjustment for all factors together. These analyses give an indication of the factors that may explain the difference in the prevalence of high NFR between the compared groups, and of the degree to which the combination of all these demographic, health, and work-related factors can explain the difference in the prevalence of high NFR. In addition to the comparison of the groups with a relatively high and low prevalence of high NFR, logistic regression analyses were used to investigate the crude relationships of the situational, work-related, and health factors with NFR. Analyses were performed using SPSS version 14.0.

\section{Results}

Table 1 shows the prevalence of high NFR for the groups that are included in the three comparisons. Please take note that columns 3 and 5 in the table contain the same group, and that columns 6 and 7 represent a more detailed overview. The prevalence was high among highly educated women of all ages $(35.2 \%)$ but was highest among highly educated women aged 50-64 years $(40.3 \%)$. This is markedly higher 
Table 1 Prevalence of high need for recovery for gender, education, and age groups (first row, italics), and the distribution of these groups over the categories of demographic, health, and work-related factors (other rows)

\begin{tabular}{|c|c|c|c|c|c|c|}
\hline & \multicolumn{2}{|c|}{ Highly educated } & \multicolumn{2}{|l|}{ Women } & \multicolumn{2}{|c|}{$\begin{array}{l}\text { Women with high } \\
\text { educational level }\end{array}$} \\
\hline & $\begin{array}{l}\text { Men } \\
(N=7,794) \\
(\%)\end{array}$ & $\begin{array}{l}\text { Women } \\
(N=6,571) \\
(\%)\end{array}$ & $\begin{array}{l}\text { With a low or } \\
\text { intermediate } \\
\text { educational level } \\
(N=15,005)(\%)\end{array}$ & $\begin{array}{l}\text { With a high } \\
\text { educational } \\
\text { level } \\
(N=6,571)(\%)\end{array}$ & $\begin{array}{l}\text { Aged } 15-49 \\
\text { years } \\
(N=5,259) \\
(\%)\end{array}$ & $\begin{array}{l}\text { Aged } 50-64 \\
\text { years } \\
(N=1,312) \\
(\%)\end{array}$ \\
\hline $\begin{array}{l}\text { Prevalence of high } \\
\text { need for recovery }\end{array}$ & 28.4 & 35.2 & 27.4 & 35.2 & 33.9 & 40.3 \\
\hline \multicolumn{7}{|l|}{ Population distribution } \\
\hline \multicolumn{7}{|l|}{ Age } \\
\hline $15-29$ & 13.4 & 22.0 & 26.2 & 22.0 & 27.4 & 0 \\
\hline $30-39$ & 28.5 & 33.0 & 24.9 & 33.0 & 41.2 & 0 \\
\hline $40-49$ & 27.2 & 25.1 & 26.8 & 25.1 & 31.4 & 0 \\
\hline $50-64$ & 30.8 & 20.0 & 22.1 & 20.0 & 0 & 100 \\
\hline \multicolumn{7}{|l|}{ Household composition } \\
\hline $\begin{array}{l}\text { Married/co-habiting } \\
\text { without children }\end{array}$ & 32.3 & 32.7 & 27.9 & 32.7 & 29.0 & 47.6 \\
\hline $\begin{array}{l}\text { Married/co-habiting } \\
\text { with children }\end{array}$ & 48.5 & 41.3 & 43.4 & 41.3 & 44.9 & 27.0 \\
\hline Single parent household & 1.4 & 4.8 & 5.7 & 4.8 & 4.6 & 5.7 \\
\hline Single & 15.3 & 18.0 & 13.2 & 18.0 & 17.9 & 18.7 \\
\hline Other & 2.6 & 3.2 & 9.8 & 3.2 & 3.7 & 1.0 \\
\hline \multicolumn{7}{|l|}{ Self-rated health } \\
\hline Excellent & 17.4 & 13.1 & 12.0 & 13.1 & 13.5 & 11.7 \\
\hline Very good & 25.2 & 24.5 & 20.8 & 24.5 & 25.6 & 20.1 \\
\hline Good & 50.1 & 53.8 & 56.4 & 53.8 & 53.5 & 55.0 \\
\hline Fair/bad & 7.3 & 8.6 & 10.9 & 8.6 & 7.5 & 13.1 \\
\hline \multicolumn{7}{|l|}{ Occupation } \\
\hline $\begin{array}{l}\text { Craft, industrial, transport } \\
\text { and agriculture workers }\end{array}$ & 5.2 & 1.1 & 7.8 & 1.1 & 1.1 & 1.1 \\
\hline Administrative workers/clerks & 6.5 & 11.8 & 25.7 & 11.8 & 12.1 & 10.5 \\
\hline Commercial and sales workers & 9.0 & 7.3 & 17.1 & 7.3 & 8.6 & 2.0 \\
\hline Service workers & 5.3 & 5.8 & 13.1 & 5.8 & 6.1 & 4.5 \\
\hline Healthcare workers & 7.7 & 24.5 & 26.5 & 24.5 & 24.3 & 25.1 \\
\hline Teachers & 11.1 & 20.2 & 1.7 & 20.2 & 16.3 & 36.2 \\
\hline Professionals & 27.6 & 9.9 & 1.0 & 9.9 & 10.8 & 6.2 \\
\hline Managers & 18.3 & 7.1 & 1.9 & 7.1 & 7.1 & 7.4 \\
\hline Other workers & 9.2 & 12.3 & 5.1 & 12.3 & 13.7 & 7.0 \\
\hline \multicolumn{7}{|l|}{$\begin{array}{l}\text { Contractual working time } \\
\text { (hours/week) }\end{array}$} \\
\hline $0-8$ & 1.6 & 3.2 & 8.8 & 3.2 & 3.2 & 3.4 \\
\hline $9-16$ & 1.6 & 7.0 & 19.0 & 7.0 & 6.3 & 9.9 \\
\hline $17-24$ & 3.0 & 24.6 & 27.9 & 24.6 & 24.0 & 27.2 \\
\hline $25-32$ & 10.1 & 28.0 & 21.3 & 28.0 & 27.9 & 28.7 \\
\hline $33+$ & 83.6 & 37.1 & 23.0 & 37.1 & 38.6 & 30.8 \\
\hline \multicolumn{7}{|l|}{ Working overtime } \\
\hline Yes, on a structural basis & 43.0 & 31.3 & 17.6 & 31.3 & 30.1 & 36.2 \\
\hline Yes, incidentally & 41.5 & 48.1 & 46.2 & 48.1 & 49.2 & 43.7 \\
\hline No, never & 15.5 & 20.6 & 36.2 & 20.6 & 20.7 & 20.1 \\
\hline
\end{tabular}


Table 1 continued

\begin{tabular}{|c|c|c|c|c|c|c|}
\hline & \multicolumn{2}{|c|}{ Highly educated } & \multicolumn{2}{|l|}{ Women } & \multicolumn{2}{|c|}{$\begin{array}{l}\text { Women with high } \\
\text { educational level }\end{array}$} \\
\hline & $\begin{array}{l}\text { Men } \\
(N=7,794) \\
(\%)\end{array}$ & $\begin{array}{l}\text { Women } \\
(N=6,571) \\
(\%)\end{array}$ & $\begin{array}{l}\text { With a low or } \\
\text { intermediate } \\
\text { educational level } \\
(N=15,005)(\%)\end{array}$ & $\begin{array}{l}\text { With a high } \\
\text { educational } \\
\text { level } \\
(N=6,571)(\%)\end{array}$ & $\begin{array}{l}\text { Aged } 15-49 \\
\text { years } \\
(N=5,259) \\
(\%)\end{array}$ & $\begin{array}{l}\text { Aged 50-64 } \\
\text { years } \\
(N=1,312) \\
(\%)\end{array}$ \\
\hline \multicolumn{7}{|l|}{ Terms of employment } \\
\hline Fixed term & 11.8 & 16.2 & 18.8 & 16.2 & 18.7 & 6.5 \\
\hline Permanent & 88.2 & 83.8 & 81.2 & 83.8 & 81.3 & 93.5 \\
\hline \multicolumn{7}{|l|}{$\begin{array}{l}\text { Size of organization } \\
\text { (number of employees) }\end{array}$} \\
\hline $1-9$ & 8.1 & 10.3 & 20.4 & 10.3 & 10.6 & 9.3 \\
\hline $10-99$ & 32.6 & 40.7 & 42.5 & 40.7 & 39.7 & 44.8 \\
\hline $100+$ & 59.3 & 49.0 & 37.1 & 49.0 & 49.8 & 45.8 \\
\hline \multicolumn{7}{|c|}{ Satisfaction with working conditions } \\
\hline (very) Dissatisfied & 9.3 & 9.6 & 10.0 & 9.6 & 9.5 & 10.2 \\
\hline Not dissatisfied/not satisfied & 15.4 & 17.3 & 19.1 & 17.3 & 16.4 & 20.5 \\
\hline Satisfied & 59.2 & 61.0 & 58.6 & 61.0 & 61.8 & 57.8 \\
\hline Very satisfied & 16.1 & 12.1 & 12.3 & 12.1 & 12.3 & 11.4 \\
\hline \multicolumn{7}{|c|}{ Job autonomy (range: $1=$ low to $3=$ high) } \\
\hline$<2.5$ & 26.0 & 38.5 & 52.9 & 38.5 & 37.2 & 43.3 \\
\hline $2.5+$ & 74.0 & 61.5 & 47.1 & 61.5 & 62.8 & 56.7 \\
\hline \multicolumn{7}{|c|}{ Time pressure (range: $1=$ never to $4=$ always) } \\
\hline$<2.5$ & 57.5 & 59.6 & 72.3 & 59.6 & 60.5 & 56.2 \\
\hline $2.5+$ & 42.5 & 40.4 & 27.7 & 40.4 & 39.5 & 43.8 \\
\hline \multicolumn{7}{|c|}{ Emotional demands (range: $1=$ never to $4=$ always) } \\
\hline$<2.5$ & 88.4 & 85.1 & 93.2 & 85.1 & 85.6 & 83.2 \\
\hline $2.5+$ & 11.6 & 14.9 & 6.8 & 14.9 & 14.4 & 16.8 \\
\hline \multicolumn{7}{|c|}{ External workplace violence and harassment } \\
\hline No, never & 79.5 & 65.7 & 68.5 & 65.7 & 65.9 & 64.8 \\
\hline Yes, at least occasionally & 20.5 & 34.3 & 31.5 & 34.3 & 34.1 & 35.2 \\
\hline \multicolumn{7}{|c|}{ Internal workplace violence and harassment } \\
\hline No, never & 84.7 & 83.5 & 87.3 & 83.5 & 83.8 & 82.2 \\
\hline Yes, at least occasionally & 15.3 & 16.5 & 12.7 & 16.5 & 16.2 & 17.8 \\
\hline
\end{tabular}

Employees with six or more positive responses to the 11 items are considered to have high need for recovery (Broersen et al. 2004)

$(p<0.001)$ than the average prevalence among all employees, which was $28.8 \%$. Table 1 further shows the population distribution over the categories of the demographic, health, and work-related factors for each of these groups.

Table 2 shows that for highly educated employees in general, and in particular for women, each situational, work-related, and health factor in our model had a significant relationship with high NFR. Logistic regression analysis shows that high NFR was more common among older employees, among those who are single or single parents, and that high NFR was relatively less common in those who rated their health positively. Furthermore, the prevalence of high NFR differed between occupational groups and was particularly high in teachers. It was highest in those with a contractual working time of at least $25 \mathrm{~h} /$ week and in those structurally working overtime. The odds of high NFR did not differ between those with a fixed term and a permanent job. Employees working in medium-sized organizations (10-99 employees) had a higher prevalence of high NFR than those working in small or large organizations. The more satisfied employees are with their working conditions, the lower the odds of high NFR. Finally, low job autonomy, high time pressure and emotional demands, and the presence of workplace violence and harassment were related with a higher prevalence of high NFR among highly educated employees. 
Table 2 Comparison of the prevalence of high need for recovery between subgroups and the crude and adjusted relationships of the demographic, health, and work-related factors with high need for recovery in these groups

\begin{tabular}{|c|c|c|c|c|c|c|}
\hline & & $\begin{array}{l}\text { Highly educated } \\
(N=13,267)\end{array}$ & \multicolumn{2}{|c|}{ Women $(N=19,234)$} & \multicolumn{2}{|c|}{$\begin{array}{l}\text { Women with high educational } \\
\text { level }(N=6,003)\end{array}$} \\
\hline & & $\begin{array}{l}\text { Women versus } \\
\text { men (ref) }\end{array}$ & \multicolumn{2}{|c|}{$\begin{array}{l}\text { Educational level high versus } \\
\text { low or intermediate (ref) }\end{array}$} & \multicolumn{2}{|c|}{$\begin{array}{l}\text { Age } 50-64 \text { versus } \\
15-49 \text { years (ref) }\end{array}$} \\
\hline & & OR $(95 \% \mathrm{CI})$ & \multicolumn{2}{|l|}{ OR $(95 \% \mathrm{CI})$} & \multicolumn{2}{|c|}{ OR $(95 \% \mathrm{CI})$} \\
\hline Crude & & $1.37(1.27-1.47)$ & \multicolumn{2}{|l|}{$1.44(1.35-1.53)$} & \multicolumn{2}{|c|}{$1.32(1.16-1.49)$} \\
\hline \multirow[t]{2}{*}{ Adjusted for all factors } & \multicolumn{2}{|c|}{$1.32(1.19-1.48)$} & \multicolumn{2}{|l|}{$1.14(1.03-1.25)$} & \multicolumn{2}{|c|}{$0.94(0.76-1.16)$} \\
\hline & $\begin{array}{l}\text { OR for eacl } \\
\text { factor } \\
(95 \% \mathrm{CI})\end{array}$ & $\begin{array}{l}\text { OR for need for } \\
\text { recovery adjusted } \\
\text { for this factor } \\
(95 \% \mathrm{CI})\end{array}$ & $\begin{array}{l}\text { OR for each } \\
\text { factor } \\
(95 \% \mathrm{CI})\end{array}$ & $\begin{array}{l}\text { OR for need for } \\
\text { recovery adjusted } \\
\text { for this factor } \\
(95 \% \mathrm{CI})\end{array}$ & $\begin{array}{l}\text { OR for each } \\
\text { factor } \\
(95 \% \mathrm{CI})\end{array}$ & $\begin{array}{l}\text { OR for need for } \\
\text { recovery adjusted } \\
\text { for this factor } \\
(95 \% \text { CI })\end{array}$ \\
\hline Age & & $1.40(1.30-1.51)$ & & $1.45(1.37-1.54)$ & & \\
\hline $15-29$ & Ref & & Ref & & & \\
\hline $30-39$ & $1.02(0.92-$ & & $1.02(0.94-1.10)$ & & NA & NA \\
\hline $40-49$ & $1.09(0.97-$ & & $1.05(0.97-1.14)$ & & & \\
\hline $50-64$ & $1.15(1.03-$ & & $1.19(1.09-1.30)$ & & & \\
\hline Household composition & & $1.35(1.25-1.45)$ & & $1.39(1.30-1.48)$ & & $1.28(1.13-1.46)$ \\
\hline $\begin{array}{l}\text { Married/co-habiting } \\
\text { without children }\end{array}$ & Ref & & Ref & & Ref & \\
\hline $\begin{array}{l}\text { Married/co-habiting } \\
\text { with children }\end{array}$ & $0.99(0.91-$ & & $0.81(0.75-0.87)$ & & $0.87(0.77-0$ & \\
\hline Single parent household & $1.44(1.17-$ & & $1.30(1.14-1.49)$ & & $1.36(1.06-1$ & \\
\hline Single & $1.24(1.12-$ & & $1.24(1.13-1.36)$ & & $1.34(1.15-1$ & \\
\hline Other & $0.79(0.63-$ & & $0.65(0.57-0.74)$ & & $0.77(0.56-1$ & \\
\hline Self-rated health & & $1.31(1.22-1.42)$ & & $1.64(1.54-1.76)$ & & $1.14(1.00-1.31)$ \\
\hline Excellent & $0.05(0.04$ & & $0.06(0.05-0.07)$ & & $0.05(0.03-0$ & \\
\hline Very good & $0.08(0.07-$ & & $0.09(0.08-0.11)$ & & $0.08(0.06-0$ & \\
\hline Good & $0.20(0.17-$ & & $0.22(0.19-0.27)$ & & $0.18(0.15-0$ & \\
\hline Fair/bad & Ref & & Ref & & Ref & \\
\hline Occupation & & $1.32(1.22-1.43)$ & & $1.31(1.22-1.41)$ & & $1.25(1.10-1.43)$ \\
\hline $\begin{array}{l}\text { Craft, industrial, } \\
\text { transport and } \\
\text { agriculture workers }\end{array}$ & $1.40(1.12-$ & & $0.84(0.72-1.00)$ & & $1.21(0.82-2$ & \\
\hline $\begin{array}{l}\text { Administrative } \\
\text { workers/clerks }\end{array}$ & $1.02(0.68-$ & & $0.77(0.68-0.88)$ & & $0.92(0.71-1$ & \\
\hline $\begin{array}{l}\text { Commercial and } \\
\text { sales workers }\end{array}$ & $1.07(0.90$ & & $0.83(0.72-0.85)$ & & $1.22(0.96-1$ & \\
\hline Service workers & $1.32(1.10$ & & $0.96(0.83-1.10)$ & & $1.31(1.01-1$ & \\
\hline Healthcare workers & $1.15(1.00$ & & $0.97(0.86-1.10)$ & & $1.03(0.86-1$ & \\
\hline Teachers & $1.69(1.46-$ & & $1.54(1.32-1.78)$ & & $1.56(1.29-1$ & \\
\hline Professionals & $0.97(0.84$ & & $1.06(0.88-1.28)$ & & $0.94(0.75-1$ & \\
\hline Managers & $0.95(0.82-$ & & $0.96(0.79-1.16)$ & & $0.87(0.68-1$ & \\
\hline Other workers & Ref & & Ref & & Ref & \\
\hline $\begin{array}{r}\text { Contractual working } \\
\text { time (hours/week) }\end{array}$ & & $1.41(1.30-1.54)$ & & $1.29(1.21-1.38)$ & & $1.34(1.18-1.53)$ \\
\hline $0-8$ & $0.79(0.61-$ & & $0.47(0.41-0.54)$ & & $0.64(0.46-0$ & \\
\hline $9-16$ & $0.88(0.73-$ & & $0.55(0.50-0.61)$ & & $0.80(0.64-0$ & \\
\hline $17-24$ & $1.05(0.94$ & & $0.74(0.68-0.80)$ & & $0.83(0.73-0$ & \\
\hline $25-32$ & $1.28(1.16-$ & & $1.02(0.94-1.11)$ & & $1.06(0.93-1$ & \\
\hline
\end{tabular}


Table 2 continued

\begin{tabular}{|c|c|c|c|c|c|c|}
\hline & $\begin{array}{l}\text { OR for each } \\
\text { factor } \\
(95 \% \mathrm{CI})\end{array}$ & $\begin{array}{l}\text { OR for need for } \\
\text { recovery adjusted } \\
\text { for this factor } \\
(95 \% \mathrm{CI})\end{array}$ & $\begin{array}{l}\text { OR for each } \\
\text { factor } \\
(95 \% \mathrm{CI})\end{array}$ & $\begin{array}{l}\text { OR for need for } \\
\text { recovery adjusted } \\
\text { for this factor } \\
(95 \% \mathrm{CI})\end{array}$ & $\begin{array}{l}\text { OR for each } \\
\text { factor } \\
(95 \% \mathrm{CI})\end{array}$ & $\begin{array}{l}\text { OR for need for } \\
\text { recovery adjusted } \\
\text { for this factor } \\
(95 \% \mathrm{CI})\end{array}$ \\
\hline $33+$ & Ref & & Ref & & Ref & \\
\hline Working overtime & & $1.46(1.35-1.56)$ & & $1.34(1.26-1.43)$ & & $1.29(1.13-1.46)$ \\
\hline Yes, on a structural basis & $1.64(1.48-1.82)$ & & $1.78(1.64-1.93)$ & & $1.87(1.62-2.17)$ & \\
\hline Yes, incidentally & $1.09(0.98-1.21)$ & & $1.17(1.09-1.25)$ & & $1.10(0.96-1.27)$ & \\
\hline No, never & Ref & & Ref & & Ref & \\
\hline Terms of employment & & $1.36(1.27-1.47)$ & & $1.43(1.34-1.52)$ & & $1.34(1.18-1.52)$ \\
\hline Fixed term & $1.01(0.91 .12)$ & & $0.97(0.89-1.05)$ & & $1.05(0.92-1.21)$ & \\
\hline Permanent & Ref & & Ref & & Ref & \\
\hline $\begin{array}{l}\text { Size of organization } \\
\quad \text { (number of employees) }\end{array}$ & & $1.35(1.26-1.46)$ & & $1.40(1.31-1.49)$ & & $1.30(1.14-1.47)$ \\
\hline $1-9$ & Ref & & Ref & & Ref & \\
\hline $10-99$ & $1.27(1.11-1.45)$ & & $1.25(1.14-1.36)$ & & $1.17(0.98-1.41)$ & \\
\hline $100+$ & $1.11(0.98-1.27)$ & & $1.32(1.21-1.45)$ & & $1.06(0.88-1.27)$ & \\
\hline $\begin{array}{l}\text { Satisfaction with } \\
\text { working conditions }\end{array}$ & & $1.32(1.22-1.42)$ & & $1.53(1.43-1.64)$ & & $1.25(1.09-1.43)$ \\
\hline (very) Dissatisfied & Ref & & Ref & & Ref & \\
\hline $\begin{array}{l}\text { Not dissatisfied/not } \\
\text { satisfied }\end{array}$ & $1.29(1.13-1.49)$ & & $1.25(1.12-1.39)$ & & $1.21(0.99-1.48)$ & \\
\hline Satisfied & $0.32(0.28-0.36)$ & & $0.33(0.30-0.37)$ & & $0.30(0.25-0.36)$ & \\
\hline Very satisfied & $0.10(0.08-0.12)$ & & $0.11(0.10-0.13)$ & & $0.10(0.07-0.13)$ & \\
\hline $\begin{array}{l}\text { Job autonomy } \\
\text { (range: } 1=\text { low } \\
\text { to } 3=\text { high) }\end{array}$ & & $1.23(1.15-1.33)$ & & $1.59(1.49-1.70)$ & & $1.25(1.10-1.42)$ \\
\hline$<2.5$ & Ref & & Ref & & Ref & \\
\hline $2.5+$ & $0.44(0.41-0.47)$ & & $0.55(0.52-0.58)$ & & $0.49(0.44-0.55)$ & \\
\hline $\begin{array}{l}\text { Time pressure } \\
\text { (range: } 1=\text { never } \\
\text { to } 4=\text { always) }\end{array}$ & & $1.56(1.35-1.58)$ & & $1.21(1.13-.129)$ & & $1.24(1.09-1.42)$ \\
\hline$<2.5$ & Ref & & Ref & & Ref & \\
\hline $2.5+$ & $4.31(4.00-4.66)$ & & $4.58(4.30-4.89)$ & & $4.15(3.72-4.63)$ & \\
\hline $\begin{array}{l}\text { Emotional demands } \\
\text { (range: } 1=\text { never } \\
\text { to } 4=\text { always) }\end{array}$ & & $1.33(1.23-1.43)$ & & $1.31(1.23-1.40)$ & & $1.27(1.12-1.45)$ \\
\hline$<2.5$ & Ref & & Ref & & Ref & \\
\hline $2.5+$ & $2.53(2.30-2.80)$ & & $3.10(2.82-3.41)$ & & $2.51(2.18-2.88)$ & \\
\hline $\begin{array}{l}\text { External workplace } \\
\text { violence and harassment }\end{array}$ & & $1.27(1.18-1.36)$ & & $1.42(1.33-1.51)$ & & $1.31(1.15-1.48)$ \\
\hline No, never & Ref & & Ref & & Ref & \\
\hline Yes, at least occasionally & $1.79(1.66-1.94)$ & & $1.78(1.67-1.89)$ & & $1.64(1.48-1.83)$ & \\
\hline $\begin{array}{l}\text { Internal workplace } \\
\text { violence and harassment }\end{array}$ & & $1.37(1.27-1.47)$ & & $1.39(1.30-1.48)$ & & $1.29(1.14-1.48)$ \\
\hline No, never & Ref & & Ref & & Ref & \\
\hline Yes, at least occasionally & $2.85(2.60-3.12)$ & & $2.76(2.54-2.99)$ & & $2.59(2.26-2.96)$ & \\
\hline
\end{tabular}

Logistic regression analyses were used in cases with no missing values for the relationships of the situational, work-related, and health factors with the need for recovery presented in columns 2,4 , and 6

Logistic regression analyses were used also for the in columns 3,5, and 7 presented relationships for, respectively, gender, educational level, and age with need for recovery. These regression coefficients presented are first, without adjustment for other factors (crude), second with adjustment for all factors mentioned in this table, and third, with adjustment for each factor separately 


\section{Gender comparison}

We compared the crude differences in the prevalence of high NFR with the adjusted differences for each factor to explore whether the gender difference would increase or decrease after adjustment for that particular factor. Column 3 of Table 2 shows that the gender difference in reporting high NFR among employees with a high educational level $(\mathrm{OR}=1.37)$ was not explained by the demographic, health, and work-related factors examined in this study. The odds ratio only marginally decreased to $\mathrm{OR}=1.32$ after adjustment for all factors together. Had our model explained gender differences in high prevalence of NFR, the odds ratio would have decreased after adjustment for all these factors. Hence, the factors combined in the model do not provide sufficient insight in gender differences although all variables in our model were significantly related to high NFR.

Looking at the single factors, we found that the lower job autonomy and higher external workplace violence and harassment explained to some extent the higher prevalence of high NFR among highly educated women than among highly educated men. If women would experience the same job autonomy and similar rates of external workplace violence as men, the gender difference in high NFR would decrease, although not completely. Highly educated women's excess in high NFR appears to be largely counterbalanced by the factors working overtime and time pressure which were reported to be higher in highly educated men. Hence, if highly educated women would work as many hours as highly educated men and under the same time pressure, the gender difference in prevalence of high NFR would be even higher.

\section{Education level comparison}

Among female employees, those with a high education level had $44 \%$ higher odds of reporting high NFR when compared with women with a low or intermediate level of education. This difference was largely explained by the demographic, health, and work-related factors, because the difference decreased to only $14 \%$ after adjustment. The higher prevalence of high NFR among women with a high educational level when compared with women with a low or intermediate educational level could largely be explained by the higher time pressure which was reported by highly educated women. Adjustment for time pressure resulted in a decrease of the OR from 1.44 to 1.21 . In addition, average contractual working time was larger in women with a high educational level, and also occupation and emotional demands explained part of the higher prevalence of high NFR among highly educated women. Better self-rated health and higher job autonomy in highly educated women, however, affected the OR in the opposite direction. Adjust- ment for these factors resulted in larger NFR differences between women with high and low or intermediate levels of education.

Age comparison

Among female employees with a high educational level, those aged 50-64 years had 32\% higher odds of reporting high NFR when compared with high educated women aged 15-49 years. The higher prevalence of high NFR in women aged 50-64 years when compared with younger women was fully explained by the differences in demographic, health, and work-related factors. Adjustment for all these factors together resulted in a decrease of the OR from 1.32 to 0.94 . The higher prevalence of high NFR among women aged 50-64 years when compared with younger women could largely be explained by the better self-reported health status of the younger women. This appears to be the most important factor explaining the difference in the prevalence of high NFR between highly educated women aged 50-64 years when compared with those aged 15-49 years. Adjustment for self-reported health resulted in a decrease of the OR from 1.32 to 1.14. Adjustment for other factors resulted in smaller changes in the relationship between age and high NFR. Except for contractual working time and terms of employment, the adjusted relationships were smaller than the crude relationship.

\section{Discussion}

Our study showed a high prevalence of work-related fatigue in highly educated female employees. In particular, women aged 50-64 years reported the highest prevalence of fatigue $(40.3 \%)$. This is in line with former findings (Van Veldhoven and Broersen 1999; Boelens 2007). In our study, work-related fatigue is clearly related to gender (women), education (highly educated women), and age (older highly educated women).

Our second research question focused on factors explaining group differences in the prevalence of fatigue. Compared with highly educated men, highly educated women more often face adverse working conditions such as lower autonomy, higher emotional demands, and external workplace violence, which increase their odds of reporting work-related fatigue. At the same time, however, the fact that they work overtime less often and more often work part-time compared with their male counterparts decreases their odds of reporting high fatigue levels. These factors counterbalance each other and therefore did not explain the gender difference in fatigue among highly educated employees. Highly educated women's high fatigue compared with women with a lower and intermediate level of 
education is largely explained by working more often under high time pressure and facing emotional demands. Comparing highly educated women aged 50-64 years with younger highly educated women, the most important explanatory factors are lower health ratings, more adverse working conditions, and working more often in the education sector.

Gender differences in high NFR among highly educated employees

Our findings that highly educated women face more often adverse working conditions compared with highly educated men, is in line with Doyal's (1995) statement that the lowstatus jobs that most women work in are most stressful. Among the highly educated, women appear to do the work that is more stressful in Dutch society, although highly educated men do tend to work more hours and structurally work overtime more often. Workplace violence offers an important explanation for fatigue among highly educated women, and we consider the high prevalence of external workplace violence among this group relevant and disturbing. Of the highly educated women, $34.3 \%$ faced external workplace violence in the past year from patients, students, or passengers compared with $20.5 \%$ of the highly educated men. Workplace violence toward women is related to 'physical proximity', which stems from higher emotional demands on women (Di Martino 2003). Working fewer hours protects highly educated women from developing even more work-related fatigue. Our results are in line with the literature that fatigue after work is related to working conditions (e.g., Jansen et al. 2003). However, additional explanations for the gender differences found are needed.

One additional explanation concerns the possibility that associations between self-reported working conditions and health are underestimated among women. A recent study showed that according to external assessors, women in active jobs with high demands and high control had more hindrances and less influence over their work, whereas men in active jobs had less hindrances and more influence over their work compared to employees' self-reports (Waldenström and Härenstam 2008). This may apply to our sample as well. Secondly, gender differences may exist in the effects of overtime work. Working overtime may serve as a safety valve allowing workers to catch up with work and reduce job stress (Åkerstedt et al. 2004). However, voluntary overtime work in some jobs may have different effects than overtime work in other jobs. For instance, an ethnographic study showed how women's capacity to provide care work in any context is endlessly stretched, including violent circumstances or working overtime (Baines 2006). Besides, overtime work may interfere with non-work duties and with leisure time. In one study, household and childcare activities were not related to NFR, but involvement in off-job activities such as sports or social contact decreased NFR (Sonnentag and Zijlstra 2006). Hence, the problem may not only be what highly educated women do as regards (overtime) work and care, but also what they do not as regards leisure. This draws attention to recovery opportunities, defined as situational characteristics that allow recuperation from work and are considered to be a subdimension of job control (Van Veldhoven and Sluiter 2009). Off-the-job recovery time can be leisure time or vacation, and our finding that working fewer hours protects women from even higher NFR indicates the influence of such factors. Finally, gender differences may also exist in on-the-job recovery time such as rest breaks, beginning or ending time, or being able to disrupt the work at will. In a recent study, among three different samples, including health care workers, on-the-job recovery opportunities explained NFR, whereas job control did not (Van Veldhoven and Sluiter 2009). Besides, gender differences may also exist in on-thejob recovery opportunities as regards unpaid work.

\section{Education differences among female employees}

Our model almost completely explained differences in fatigue between women of different education levels. Particularly, highly educated women work more often under time pressure and face higher emotional demands. The role of time pressure in fatigue is in line with the JD-C model (Karasek and Theorell 1990). Highly educated women's better health status compared with lower educated women partly protects them from fatigue.

Age differences among highly educated female employees

Health also plays a role in the comparison between age groups. Compared with their younger counterparts, highly educated older women's high NFR is mainly explained by their lower health ratings, and additionally by working more as teachers and working more often under time pressure. Age differences between highly educated women are well explained by our model. The adverse working conditions that older women face may be related to the fact that they work more often in the education sector (16.3 vs. $36.2 \%$ ). Possibly, younger women have more options as regards occupational choices than their older counterparts who may have been tracked into education.

\section{Limitations and strengths to the study}

Our study is representative for Dutch employees, but may not generalize to other countries because of the high parttime work rates in the Netherlands (Visser 2002). A double burden of work and care may exist in other countries, where traditional roles are largely intact at home, while 
women participate full-time in the labor market, such as in the United States. Furthermore, we did not include how the respondents experience their work-life balance, and whether gender equality exists as regards domestic work. Higher strain in domestic work was found to be associated with lower mental health scores in working women (Staland-Nyman et al. 2008).

Comparing the three subgroups seemed meaningful, but other comparisons might have provided additional explanations. For instance, lower educated men spend more hours caring for their children than highly educated men (Verdonk and De Rijk 2008) and more often combine high physical job demands with lower control at work. Hence, their lives may be more comparable to highly educated women's working lives than the groups chosen.

We did not control for the presence of chronic disease. A stronger healthy worker effect is to be expected among highly educated women older than 50 than among their male counterparts, because ill-health may play a role in women's lower labor market participation (Abramson 2007). Hence, better self-reported health was to be expected in highly educated women than in highly educated men, but this was not found in our data. Nevertheless, health status is important in the mental effort necessary to perform a job. The prevalence of long-term disease such as a heart condition or psychological problems is associated with NFR, and working requests relatively more effort from people with psychosomatic health complaints (Jansen et al. 2003; Meijman and Zijlstra 2007). Job autonomy is even more important for workers with health problems, because control enables them to efficiently deal with their energy.

\section{Implications for research}

Only by the end of the 1980s, Dutch women's labor market participation strongly increased. Although highly educated women have always worked more than lower educated women, the older women in our sample may be the pioneers of their generation and possibly, our findings must be attributed to a cohort-effect rather than an age-effect. Qualitative research may provide more insight into the process of developing stress complaints and fatigue in highly educated older women, how they experience their work history, their current working and private lives, and their health care needs.

Our findings suggest that work is more costly in terms of effort for highly educated women than for their male counterparts in the workforce. Gender-specific factors such as difficulties in setting limits or putting high demands on oneself are often overlooked in measures of work stress (Holmgren et al. 2009). For instance, in a study among 8,000 MBA students, researchers found that women scored higher than men on the value of wanting to do an excellent job (Frieze et al. 2006). These values are worth studying in relation to fatigue. Besides, given the recent findings that on-the-job recovery opportunities impact on employees' health and NFR (Van Veldhoven and Sluiter 2009), gender differences in on-the-job recovery opportunities warrant further investigation.

A study combining external assessments of job demands and control with self-reports in a high-risk sector such as education may provide more insight in possible gender differences in working conditions and their meanings. Besides, large surveys should not only focus on job characteristics and demographic variables but also include topics such as informal care and its intensity as well as recovery opportunities.

As regards health care for women, we need to develop and study interventions to help highly educated women cope with their strains and to help balance their energy. And last but not least, workplace violence needs to be studied and targeted, in particular in health care and in education.

\section{Implications for practice}

Highly educated women are generally satisfied with their work. Moreover, our finding that highly educated women have high levels of fatigue does not contradict former findings that women, including older women, experience their lives as positive and meaningful (Boelens 2007; Gordon et al. 2002). There is, however, some room for improvement. As regards the organizational level, workplace violence must be addressed for instance by raising awareness, assertiveness training, alarm systems, and counseling. Family-friendly policies focusing on child care are not sufficient for older women who start having responsibilities for caring for their own parents within the context of large jobs. Our findings may also have implications for health care for highly educated women with fatigue complaints. In particular, women with stress problems may benefit from active coaching to change stressful interactions at work (Van Veldhoven 2008; Verdonk et al. 2008).

In the Netherlands, expectations for the future are that the female workforce will continue to grow and will demonstrate even higher levels of education. Extrapolating our findings to this future scenario, our findings imply a strong call for attention: work-related fatigue in highly educated women needs a firm place on the policy, research, and occupational health care agenda.

Conflict of interest The authors declare that they have no conflict of interest.

Open Access This article is distributed under the terms of the Creative Commons Attribution Noncommercial License which permits any noncommercial use, distribution, and reproduction in any medium, provided the original author(s) and source are credited. 


\section{References}

Abramson Z (2007) Masked symptoms: mid-life women, health, and work. Can J Aging 26:295-304

Åkerstedt T, Knutsson A, Westerholm P, Theorell T, Alfredsson L, Kecklund G (2004) Mental fatigue, work and sleep. J Psychosom Res 57:427-433. doi:10.1016/j.jpsychores.2003.12.001

Baines D (2006) Staying with people who slap us around: gender, juggling responsibilities and violence in paid (and unpaid) care work. Gend Work Organ 13:129-151. doi:10.1111/j.1468-0432.2006.00300.x

Bakker AB, Demerouti E, Schaufeli WB (2002) Validation of the Maslach Burnout inventory-general survey: an internet study. Anxiety Stress Coping 15:246-260. doi:10.1080/106158002 1000020716

Bekker MHJ, Croon MA, Bressers B (2005) Childcare involvement, job characteristics, gender and work attitudes as predictors of emotional exhaustion and sickness absence. Work Stress 19:221-237. doi:10.1080/02678370500286095

Bensing JM, Hulsman RL, Schreurs KMG (1999) Gender differences in fatigue: biopsychosocial factors relating to fatigue in men and women. Med Care 37:1078-1083

Boelens L (2007) Vrouwen van 50. Lef, lust en nieuwe ambitie (Women of 50. Guts, lust and new ambitions). Amsterdam: Archipel

Broersen JPJ, Fortuin RJ, Dijkstra L, Van Veldhoven M, Prins J (2004) Monitor Arboconvenanten: kengetallen en grenswaarden. TBV 12:100-104

De Croon EM, Sluiter JK, Frings-Dresen MHW (2003) Need for recovery after work predicts sickness absence. A 2-year prospective cohort study in truck drivers. J Psychosom Res 55:331-339. doi:10.1016/S0022-3999(02)00630-X

De Croon EM, Sluiter JK, Blonk RWB, Broersen JPJ, Frings-Dresen MH (2004) Stressful work, psychological job strain, and turnover: a 2-year prospective cohort study of truck drivers. J Appl Psychol 89:442-454

De Croon EM, Sluiter JK, Frings-Dresen MHW (2006) Psychometric properties of the need for recovery after work scale: test-retest reliability and sensitivity to detect change. Occup Environ Med 63:202-206. doi:10.1136/oem.2004.018275

Di Martino V (2003) Workplace violence in the health sector. Relationship between work stress and workplace violence in the health sector. Geneva: International Labor Organization/the International Council of Nurses/World Health Organization/Public Services International. Download 3 February from https:// www.who.int/violence_injury_prevention/violence/interpersonal/ en/WVstresspaper.pdf

Doyal L (1995) What makes women sick? Gender and the political economy of health. Rutgers University Press, New Brunswick

Doyal L, Payne S (2006) Older women, work and health. Reviewing the evidence. London: The Age and Employment Network. Download 1 February 2009 from http://www.taen.org.uk/Publications/Older\%20women,\%20Work\%20and\%20Health.pdf

Frieze I, Olson JE, Murrell AJ, Mano S (2006) Work values and their effect on work behavior and work outcomes in female and male managers. Sex Roles 54:83-93. doi:10.1007/s11199-006-8871-z

Gordon JR, Beatty JE, Whelan-Berry KS (2002) The midlife transition of professional women with children. Women Manag Rev 17:328-341. doi:10.1108/09649420210445785

Holmgren K, Hensing G, Dahlin-Ivanoff S (2009) Development of a questionnaire assessing work-related stress in women-identifying individuals who risk being put on sick leave. Disabil Rehabil 31:284-292. doi: 10.1080/09638280801931287

Jansen NWH, Kant IJ, Van Amelsvoort LGPM, Nijhuis FJN, Van den Brandt PA (2003) Need for recovery from work: evaluating shortterm effects of working hours, patterns and schedules. Ergonomics 46:664-680. doi:10.1080/0014013031000085662
Kant IJ, Bültmann U, Schroër KAP, Beurskens A, Van Amelsvoort LGPM, Swaen G (2003) An epidemiological approach to study fatigue in the working population: the Maastricht Cohort study. Occup Environ Med 60:i32-i39. doi:10.1136/oem.60.suppl_1.i32

Karasek R, Theorell T (1990) Healthy work: stress, productivity and the reconstruction of working life. Basic Books, New York

Karasek R, Brisson C, Kawakami N, Houtman I, Bongers P, Amick B (1998) The Job Content Questionnaire (JCQ): an instrument for internationally comparative assessments of psychosocial job characteristics. J Occup Health Psychol 3:322-355

Kiss P, De Meester M, Braeckman L (2008) Differences between younger and older workers in the need for recovery after work. Int Arch Occup Environ Health 81:311-320. doi:10.1007/s00420007-0215-y

Lautenbach H (2006) Relatie meervoudige werkbelasting en burn-out bij vrouwen (Relationship between double burden and burn-out in women). Soc Econ Trends 2:11-14

Macintyre S, Hunt K, Sweeting H (1996) Gender differences in health: are things really as simple as they seem? Soc Sci Med 42:617624. doi:10.1016/0277-9536(95)00335-5

Meeuwesen L, Bensing J, Van den Brink-Muinen A (2002) Communicating fatigue in general practice and the role of gender. Patient Educ Couns 48:233-242

Meijman TF, Mulder G (1998) Psychosocial aspects of workload. In: Drenth PJD, Thierry H, Wolff CJ (eds) Handbook of work, organizational psychology. Psychology Press, Hove, pp 5-33

Meijman TF, Zijlstra FRH (2007) Arbeid en mentale inspanning. In: Schaufeli WB, Bakker A (eds) De psychologie van arbeid en gezondheid (The psychology of work and health). Bohn Stafleu Van Loghum, Houten, pp 51-70

Nelson DL, Burke RJ (2002) Gender, work and health. American Psychological Association, Washington

Otten F, Smulders P, Andries F (2002) Arbeidsuitval door burn-out (Sickness absence due to burn-out). Econ Stat Ber 4:11-13

Peretti-Watel P, Legleye S, Baumann M, Choquet M, Falissard B, Chau N, The Lorhandicap group (2009) Fatigue, insomnia and nervousness: gender disparities and roles of individual characteristics and lifestyle factors among economically active people. Soc Psychiatry Psychiatr Epidemiol. On-line first. doi: 10.1007/ s00127-008-0487-x

Portegijs W, Cloïn M, Keuzenkamp S, Merens A, Steenvoorden E (2008) Verdeelde tijd. Waarom vrouwen in deeltijd werken (Divided time. Why women work part-time). Den Haag: Sociaal en Cultureel Planbureau. Download 11 November 2008 from http://www.scp.nl/publicaties/boeken/9789037703979/Verdeelde\% 20tijd.pdf

Pugliesi K (1999) Gender and work stress: differential exposure and vulnerability. J Gend Cult Health 4:97-117. doi:10.1023/ A: 1023257726254

Sluiter JK, De Croon EM, Meijman TF, Frings-Dresen MHW (2003) Need for recovery from work related fatigue and its role in the development and prediction of subjective health complaints. Occup Environ Med 60(Suppl 1):i62-i70. doi:10.1136/oem.60.suppl_1.i62

Smulders P, Klein Hesselink J (1999) Agressie en geweld op het werk (Agression and violence at work). In: Houtman ILD, Smulders PGW, Klein Hesselink DJ (eds) Trends in Arbeid 1999 (Trends in Work 1999). Alphen aan den Rijn: TNO Arbeid/Samsom, pp 107-129

Sonnentag S, Zijlstra FRH (2006) Job characteristics and off-job activities as predictors of need for recovery, well-being, and fatigue. J Appl Psychol 91:330-350

Staland-Nyman C, Alexanderson K, Hensing G (2008) Associations between strain in domestic work and self-rated health: a study of employed women in Sweden. Scand J Public Health 36:21-27. doi: $10.1177 / 1403494807085307$ 
Swaen GMH, Van Amelsvoort LGPM, Bültmann U, Kant IJ (2003) Fatigue as a risk factor for being injured in an occupational accident: results from the Maastricht Cohort study. Occup Environ Med 60(Suppl I):i88-i92. doi:10.1136/oem.60.suppl_1.i88

Twellaar M, Winants Y, Houkes I (2008) How healthy are Dutch general practitioners? Self-reported (mental) health among Dutch general practitioners. Eur J Gen Pract 14:4-9. doi:10.1080/ 13814780701814911

Van Amelsvoort LGPM, Kant IJ, Bültmann U, Swaen GMH (2003) Need for recovery after work and the subsequent risk of cardiovascular disease in a working population. Occup Environ Med 60(Suppl. 1):i83-i87. doi:10.1136/oem.60.suppl_1.i83

Van den Bossche SNJ, Hupkens CLH, De Ree SJM, Smulders PGW (2006) Nationale Enquête Arbeidsomstandigheden 2005: Methodologie en globale resultaten (Netherlands Working Conditions Survey 2005: methodology and overall results). Hoofddorp: TNO Work \& Employment

Van den Bossche SNJ, Hupkens CLH, De Ree SJM, Smulders PGW (2007) Nationale Enquête Arbeidsomstandigheden 2006: Methodologie en globale resultaten (Netherlands Working Conditions Survey 2006: methodology and overall results). Hoofddorp: TNO Work \& Employment

Van Veldhoven M (2008) Need for recovery after work: an overview of construct, measurement and research. In: Houdmont J, Leka S (eds) Occupational health psychology: European perspectives on research, education, practice, vol III. Nottingham University Press, Nottingham, pp 1-25

Van Veldhoven M, Broersen S (1999) Psychische vermoeidheid in de arbeidssituatie. Een verkenning op basis van gegevens verzameld door arbodiensten (Psychological fatigue at work. An exploration based on data collected by occupational health services). Gedrag Organ 12:347-363

Van Veldhoven M, Broersen S (2003) Measurement quality and validity of the 'need for recovery scale'. Occup Environ Med 60(Suppl. 1):i3-i9. doi:10.1136/oem.60.suppl_1.i3

Van Veldhoven M, Sluiter JK (2009) Work-related recovery opportunities: testing scale properties and validity in relation to health. Int Arch Occup Environ health. Online First. doi: 10.1007/s00420009-0411-1

Van Veldhoven M, Meijman TF, Broersen JPJ, Fortuin RJ (2002) Handleiding VBBA (Manual QEEW). Amsterdam: Stichting Kwaliteitsbevordering Bedrijfsgezondheidszorg. Download 15 September 2009 from http://www.skbvs.nl/bestanden/www.skbvs.nl_20030716_handleiding_vbba.pdf

Verdonk P, De Rijk A (2008) Loopbaansucces en welbevinden van Nederlandse werknemers M/V (Career success and well-being in Dutch employees M/F). Gedrag Organ 21:451-474

Verdonk P, De Rijk A, Klinge I, De Vries A (2008) Sickness absence as interactive process: gendered experiences of young, highly educated women with mental health problems. Patient Educ Couns 73:300-306. doi:10.1016/j.pec.2008.06.003

Visser J (2002) The first part-time economy in the world: a model to be followed? J Eur Soc Policy 12:23-42. doi:10.1177/ 0952872002012001561

Waldenström K, Härenstam A (2008) Does the job demand control model correspond to externally assessed demands and control for both women and men? Scand J Public Health 36:242-249. doi: $10.1177 / 1403494807085079$ 